\title{
The Motivation of Learners of Arabic: Does it Decrease with Age?
}

\author{
Pauline Ghenghesh \\ Department of English Language, the British University in Egypt, \\ El Sherouk City, Postal No. 11837, P.O. Box 43, Cairo, Egypt \\ E-mail: paulineghenghesh@yahoo.co.uk
}

\begin{abstract}
This study investigated the motivation of a heterogeneous group of students studying Arabic as a second language at the International School in Tripoli area. The aim of the study was to find out the extent to which various factors affect students' motivation and achievement in second language learning particularly as they enter the senior high school. The research also looked into the temporal dimension of L2 motivation to see if the students' motivation changes as they enter the senior high school. One hundred and forty four students from thirty five nationalities learning Arabic and four teachers participated in the completion of the questionnaire surveys. Twenty students and two teachers took part in the semi-structured interviews. Data were drawn from students' examination results and a combined quantitative-qualitative approach in which student and teacher questionnaire surveys were followed by a round of student and teacher interviews. The results of the 'Student's Motivation Questionnaire' show that L2 motivation in the sample decreases with age. The results of one-way analyses of variance across the five age groups investigated show that the older learners tend to score significantly lower on the motivational scales and the interviews data gives further support to this finding. There are a number of influential factors that affect learners' motivation: in particular the role of the teacher was seen fundamental in determining the attitude to the language and in supplying motivation. Other external factors include aspects related to the learning context.
\end{abstract}

Index Terms - motivation, L2 learners, achievement, learning context, second language

\section{INTRODUCTION}

It has been commonly accepted that the learners' achievement in learning a second/foreign language is related to their level of motivation to learn the language. Motivation is a kind of internal drive that encourages a learner to pursue a course of action and is responsible for initiating the learning and later the driving force to sustain the learning process over the long and arduous years it takes to learn a language. It is believed that without sufficient motivation no other factor on its own can ensure student achievement (Dörnyei, 2001).

The first three decades of L2 motivation research saw a considerable amount of empirical investigations which were mostly inspired by Robert Gardner and his associates in Canada applying versions of a standardised motivation test. The results of this research have demonstrated that attitudes and motivation are related to how well individuals learn a second/foreign language. By the early 1990s the study of motivation took a turning point following a call to arms by Crookes \& Schmidt (1991) to explore various directions in which the social psychological construct of L2 motivation could be further developed. As a result of this, the 1990s saw an influx of L2 research that extended and covered a variety of issues, particularly cognitive and situation-specific variables.

Amongst some of the researchers who have made an invaluable contribution to our understanding of L2 motivation are Williams \& Burden (1997). These authors reviewed a substantial number of general motivational theories as well as some recent research on L2 motivation. The different aspects of this research have been presented in the form of a framework of motivational factors.

Similarly, Dörnyei (1994) attempted to integrate the various components of motivation and at the same time focus on the components that would be applicable to foreign language learning contexts as opposed to second language learning contexts. He drew up an extended motivational framework which was similar in nature but broader to that of Crookes \& Schmidt's (1991) approach. The tripartite division of the framework was also based on the empirical results of Clément, Dörnyei \& Noels, (1994) classroom study in Hungary in which a tripartite L2 motivation construct emerged comprising integrativeness, linguistic self-confidence and the appraisal of the classroom environment. Using this as the basis, Dörnyei developed a more general framework of L2 motivation. This framework consists of three relatively distinct levels.

The first level is The Language Level which comprises the Integrative Motivational Subsystem and the Instrumental Motivational Subsystem. The second level of this motivational construct is the Learner Level, which involves various cognitive aspects of motivation which form part of the 'baggage' that a person brings to the learning process. The third level of motivation is the Learning Situation Level which involves three sub-categories of motivational components. They are: 1. Course-Specific Motivational Components, 2. Teacher-Specific Motivational Components and 3. Group- 
Specific Motivational Components.

A number of researchers have found that there is a strong connection between the teacher and the learners' motivation, achievement, negative feelings and effort (Chambers, 1998; Clément et al , 1994; Gardner, Masgoret, Tennant, Mihic, 2004; Mihaljević, 1990, 1992, 1994; Nikolov, 1999; Ozek \& Williams, 1999; Ryan \& Patrick, 2001; Williams \& Burden, 1999; Williams, Burden \& Al-Baharna, 2001; Guilloteaux \& Dörnyei, 2009; Hardré \& Sullivan, 2008). The results of these studies highlight the fact that "the teacher's level of enthusiasm and commitment is one of the most important factors that affect the learners' motivation" (Dörnyei, 1998, p. 130).

Furthermore, other external factors such as the course, teaching methods, instructional materials, influences of family, friends, learning activities and even individual tasks can affect the learners' motivation, achievement, effort, and develop positive or negative feelings (Chambers, 1998; Dörnyei, 1994, 2002; Dörnyei, 2008; Donitsa-Schmidt, Inbar \& Shohamy, 2004; Egbert, 2003; Ellis, 1985; Inbar, Shohamy \& Donitsa-Schmidt, 1999, 2001; Julkunen, 1990, 1994, 2001; Mihaljević, 1990, 1994; Ozek \& Williams, 1999; Williams \& Burden, 1999; Williams et al, 2001).

A review of the literature on motivation in an educational context reveals that even though research has been carried out on student motivation, only a few studies have been conducted analysing the dynamics of L2 motivational change in educational institutions (Chambers, 1999; Williams \& Burden, 1999; Williams, Burden \& Lanvers, 2002; Tachibaba, Matsukawa \& Zhong, 1996; Gardner, Masgoret, Tennant \& Mihic, 2004) despite the fact that the learners' interest needs to be sustained over the many years it takes to learn a language. It appears logical therefore, that research on the temporal dimension of L2 motivation is important to our understanding of the different influential factors that affect learners throughout the lengthy process of their study.

Since the results of the above studies suggest that the motivation of learners in school contexts declines with age and that it is influenced by external factors related to the teacher and course-specific motivational components outlined in Dörnyei's (1994) framework of L2 motivation, the objectives of the current study were to find out: (a) the extent in which various factors affect students' motivation and achievement in second language learning particularly as they enter the senior high school; (b) to carry out a cross-comparison of the results obtained by the questionnaire with those of the interviews and (c) to obtain additional information on how students motivation can be enhanced.

\section{METHOD}

\section{A. Participants}

The participants in this study were students and teachers from the 'International School of the Martyrs' in the Tripoli area. One hundred and forty four students from thirty five nationalities learning Arabic participated in the questionnaire survey. The participants were selected from five different levels: Grades $6-10$. All the participants in these levels who were present on the days the questionnaire was administered took part in the completion of this instrument. Questionnaire Item 116 sought to find out what the students' first language was (and not whether they were native or non-native speakers of the language), and the answers indicate that 38 students constitute 'English as a first language group' and 54 'Arabic as a first language group'. The students' grades, gender and language proficiency level are summarised in Table 1.

TABLE 1.

GRADES, GENDER AND LANGUAGE PROFICIENCY LEVEL OF STUDENTS

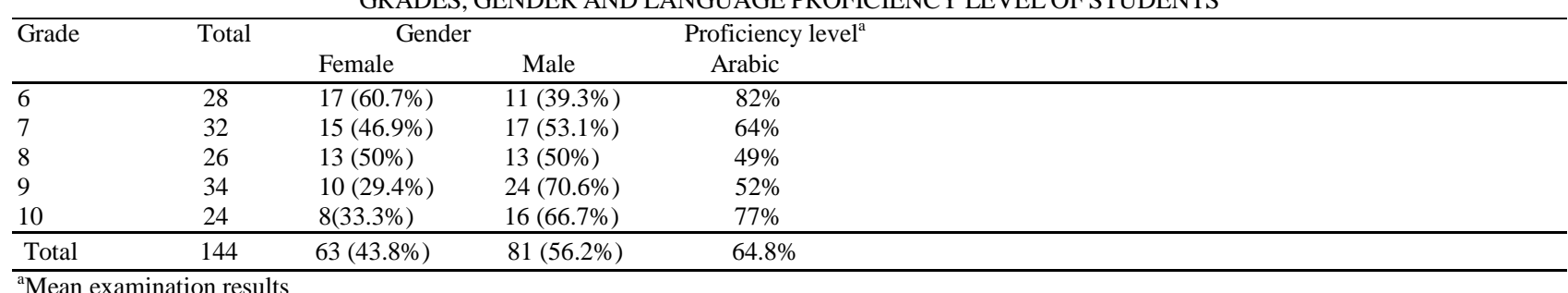

In all, four teachers participated in the completion of the 'Teacher's Evaluation of Student's Motivation Questionnaire', two from the elementary school and two from the high school. The four teachers are of Arab origin.

There were twenty students ( 8 males and 12 females) that took part in the semi-structured interviews. They constitute four ethnic backgrounds: Europeans (6); Asians (1); Arabs (11) and Africans (2). Eight students were selected from Grade 8, six from Grade 9 and six from Grade 10. Students were chosen according to the following criteria:

- They had completed the student questionnaire.

- They were sufficiently talkative to allow for the gathering of rich data.

- They were available at the time of the interviews.

The two Arabic teachers that participated in the semi-structured interviews are both of Arab origin. The criteria that was used for teacher selection was based on which levels the teachers had taught.

\section{B. Instruments}

Data were collected using both quantitative and qualitative methods. In all a total of four research instruments were 
devised for this study: a questionnaire for students, a questionnaire for teachers, one round of semi-structured interviews for students and a semi-structured interview for teachers. In addition to this the achievement scores of the first-term examination were provided by each class teacher.

\section{Procedures}

The investigation consisted of four stages. For the initial stage a Student's Motivation Questionnaire was administered to all students in Grades 6-10 during their regular class time. The questionnaire consisted of 101 statements, questions and bipolar adjectives, which required the students to respond to the items by simply evaluating a statement/question on a five-point Likert scale or marking their responses on seven-point semantic differential scales. In addition, two open-ended statements provided the students with the opportunity to include their own ideas on ways which they thought could help them learn these languages. The questionnaire also sought to obtain background information about the students. The main part of the questionnaire consisted of 101 items about the learning of Arabic, representing 19 motivational variables. The number of items for each variable varied from two to fourteen. Table 2 presents the main variables that were used in this study and number of items that addressed them.

TABLE 2.

THE MAIN VARIABLES IN THE QUESTIONNAIRE AND THE NUMBER OF ITEMS FOR EACH

\begin{tabular}{lc}
\hline Variables & Number of Items \\
\hline Orientations to Learning Arabic & 14 \\
Attitudes Toward Studying Arabic & 8 \\
Frequency of Contact with Native- Speaking People & 3 \\
Frequency of Contact with Target Language & 3 \\
Quality of Contact with Native-Speaking People & 7 \\
Quality of Contact with Target Language & 4 \\
Attitudes Toward L2 Community & 4 \\
Parental Encouragement & 4 \\
Parents Expectations & 4 \\
Friends Influences & 5 \\
Anxiety in Class & 3 \\
Arabic Use Anxiety & 6 \\
Expectations & 7 \\
Effort & 6 \\
Self-Evaluation of Arabic & 6 \\
Desired Arabic Proficiency & 6 \\
Satisfaction & 2 \\
Attitudes Toward the Arabic Lessons & 4 \\
Attitudes Toward the Arabic Textbook & 4 \\
\hline
\end{tabular}

For the second stage of data elicitation the 'Teacher's Evaluation of Student's Motivation Questionnaire' was devised for the teachers who taught the classes that took part in this study. This instrument consisted of three items which focused on the teachers' perception of (a) the motivation of the students to learn these languages; (b) how active they were in class; (c) how conscientious they were towards their homework assignments. For each item the teachers were asked to respond by marking an option on a 7 point-semantic differential scale. The aim of this instrument was to collect performance data about the students and, based on this, to select students to participate in the subsequent interview sessions.

For the third and fourth stages of data collection, semi-structured interview techniques were used for students and teachers. It was believed that the data collected by this method would enable the students to elaborate on the issues raised in an exploratory manner and allow the researcher to explore the underlying patterns of thinking that go beyond the surface level answers on questionnaires.

The interviews were conducted with the students and teachers during the regular school time. The interview questions for students and teachers are as follows:

\section{Students}

a. How important is it for you to study Arabic?

b. Has your motivation to learn Arabic changed over the years, if so why?

c. What can the school do to enhance your motivation?

d. How can teachers help increase your motivation?

e. What other things would help increase your motivation?

2. Teachers

a. Do you think there is a change in students' motivation as they grow older, if so why do you think this is?

b. What do you think the school can do to enhance student motivation?

c. What can teachers do to help increase student motivation?

\section{Data Analysis}

The data obtained from the Student's Motivation Questionnaire was computer coded and processed with the Statistical Package for the Social Sciences (SPSS) version 9.2. The negatively worded statements were recoded before 
calculating the composite scale scores. The 'Teacher's Evaluation of Student's Motivation Questionnaire' and the Achievement scores were also analysed using the SPSS.

The analytical procedure consisted of four phases. Firstly, in order to check if the scales in our 'Student's Motivation Questionnaire' were reliable, the researcher computed for each scale the Cronbach Alpha internal consistency reliability coefficient. Items which reduced the internal consistency of a scale were omitted from the scales before further analytical procedures were carried out. As can be seen in Table 3 most figures meet acceptable levels of reliability.

TABLE 3.

NUMBER OF ITEMS, RELIABILITY COEFFICIENT AND SAMPLE ITEMS FOR ALL SCALES

\begin{tabular}{|c|c|c|c|}
\hline $\begin{array}{l}\text { Motivational } \\
\text { Scales }\end{array}$ & $\begin{array}{c}\# \\
\text { Items }\end{array}$ & Arabic & Sample Item \\
\hline Instrumental Orientation & 9 & .84 & $\begin{array}{l}\text { Studying this languages is } \\
\text { necessary for my future } \\
\text { educational plans. }\end{array}$ \\
\hline Integrative Orientation & 9 & .84 & $\begin{array}{l}\text { Studying this languages will } \\
\text { allow me to get to know people } \\
\text { from different parts of the world. }\end{array}$ \\
\hline $\begin{array}{l}\text { Attitudes Towards } \\
\text { Studying }\end{array}$ & 7 & .63 & I really enjoy studying this \\
\hline $\begin{array}{l}\text { Frequency of Direct } \\
\text { Contact }\end{array}$ & 3 & .87 & $\begin{array}{l}\text { How often do you converse with } \\
\text { students at school whose first } \\
\text { language is Arabic? }\end{array}$ \\
\hline $\begin{array}{l}\text { Frequency of Indirect } \\
\text { Contact }\end{array}$ & 7 & .88 & $\begin{array}{l}\text { How often do you watch TV in } \\
\text { this language? }\end{array}$ \\
\hline $\begin{array}{l}\text { Quality of Contact } \\
\text { with language }\end{array}$ & 7 & .81 & $\begin{array}{l}\text { How much do you enjoy } \\
\text { watching TV in this language? }\end{array}$ \\
\hline $\begin{array}{l}\text { Quality of Direct } \\
\text { Contact }\end{array}$ & 3 & .73 & $\begin{array}{l}\text { How much do you enjoy } \\
\text { conversing with people in general } \\
\text { whose first language is Arabic? }\end{array}$ \\
\hline $\begin{array}{l}\text { Parental Influence } \\
\text { is important to learn. }\end{array}$ & 8 & .84 & My parents think this language \\
\hline Anxiety & 6 & .66 & $\begin{array}{l}\text { I feel embarrassed when I speak } \\
\text { in front of the class. }\end{array}$ \\
\hline Expectations & 4 & .84 & $\begin{array}{l}\text { I expect to be able to speak } \\
\text { fluently and at ease with someone } \\
\text { in this language. }\end{array}$ \\
\hline Effort & 6 & .53 & $\begin{array}{l}\text { Do you complete your assignments } \\
\text { in this subject? }\end{array}$ \\
\hline Self-Evaluation & 6 & .93 & I read this language. \\
\hline Desired Proficiency & 6 & .83 & $\begin{array}{l}\text { I would like to be able to read in } \\
\text { this language. }\end{array}$ \\
\hline Satisfaction & 2 & .74 & $\begin{array}{l}\text { Are you satisfied with your class } \\
\text { work in this subject? }\end{array}$ \\
\hline Attitudes Lessons & 4 & .71 & enjoyable - not enjoyable \\
\hline Attitudes Textbook & 4 & .80 & interesting - not interesting \\
\hline Motivated Behaviour & 3 & .93 & motivated - not motivated \\
\hline Total: mean coefficients & & .79 & \\
\hline
\end{tabular}

Secondly a correlational analysis using Pearson Product-Moment Correlations was conducted to identify the interrelationship between the motivational variables and to examine the relationship between those factors and effort, motivated behaviour and achievement scores. Thirdly, a One-way analysis of variance (ANOVA) was performed to compare the mean scores of the motivational variables, effort and motivated behaviour across the various age groups. Fourthly, Post-hoc tests were conducted to find out which groups were significantly different to each other.

The semi-structured interviews were tape-recorded and transcribed. The data were content analysed in two groups, Grade 8 and Grades 9 and 10 in order to look for patterns and relationships within the text and compare responses between the different age groups. Notes were taken of student's answers and were listed in specific descriptive phrases that could be presented and read in a clear and comprehensible fashion. At the end of the analysis there was one complete table illustrating the responses to the questions. As with the students' interviews the tape-recorded interviews of the teachers were analysed in a similar fashion to that of the students.

\section{RESULTS \& DISCUSSION}

\section{A. Questionnaire}

Reliability of the student's motivation questionnaire

By grouping items that measured the same target area it was possible to obtain multi-item scales and compute total scale scores for them. Based on theoretical considerations and a series of reliability analyses, seventeen such scales were produced from the 101 items contained in the student's questionnaire and the three items from the teacher's questionnaire - the scales are described in Table 3. The internal consistency reliability of each of these subscales was 
measured by the Cronbach's Alpha coefficient. These coefficients ranged from .53 to .93 with a mean coefficient of .79. Generally the more items a category contains, the higher the reliability estimate. Therefore, given the relative shortness of the scales, most of these estimates are acceptably high.

\section{B. Correlational Analyses}

\section{The whole sample}

Following the reliability analysis, a correlation analysis was conducted to identify the interrelationship of the motivational variables and to examine the relationship of those factors with effort, motivated behaviour and achievement scores. The motivated behaviour scores were obtained from the 'Teacher's Evaluation of Student's Motivation Questionnaire'. The achievement scores were based on the first term examination marks of the school year.

The correlations for the whole sample $(n=144)$ consisting of fourteen motivational scales with the criterion measures are displayed in Table 4. As can be seen many coefficients are significant - there are a total of twenty eight in all. Most significant correlations emerged with 'Effort'. This was to be expected because effort in this study was operationalised as 'intended effort' and was measured with the same item format and item type as the motivational variables. Although most of the motivational variables have a significant positive correlation with the criterion measure 'Effort', it is only 'Desired Arabic proficiency', 'Attitudes towards the Arabic lessons' and Attitudes towards the Arabic textbook' that have shown a highly significant positive relationship (i.e. significant at the $p<.01$ level) with all the three criterion measures: 'Effort', 'Motivated behaviour' and 'Examination results'. This confirms the situation-specific emphasis of motivational studies that emerged after the educational shift. Further confirmation of this trend was obtained by the fact three other scales, 'Expectations of Arabic', 'Self evaluation of Arabic' and 'Satisfaction with Arabic' have a significant correlation with the learning context comprising the lessons and are therefore major determinants of effort to do well in Arabic classes. The impact of the learning context is also reflected by the correlation between 'Attitudes towards studying Arabic' with 'Effort' and 'Motivated behaviour.'

The criterion measure 'Motivated behaviour' has produced many significant correlations with the motivational scales. This may be related to the fact that the cultural perspective of what constitutes motivated student behaviour is different from an Anglophone and Arabic perspective. Arabic teachers, whose evaluation formed the basis of this measure, link perceived student motivation to a well-defined set of behaviours which the students are to perform in the more traditional framework of the language classes. As evidenced by the correlations in Table 4 these behaviours are indeed a good reflection of the students' motivation.

The 'Frequency of direct contact scale' did not produce any significant results, which is quite surprising as fifty four students that took part in this study actually fall into the category of 'Arabic as a first-language group'. Besides this, Arabic is taught as a second language at the International School as it is the official language spoken in Libya and students are surrounded at school and outside the school setting by people who use it as the main vehicle of everyday communication. Therefore one would certainly expect these students to have more opportunities of contact with native speakers. One possible explanation for this lack of personal contact with the L2 community is related to the students' learning and living environments. At the initial stages of administering this questionnaire, there were four hundred and twenty eight students enrolled at the International School from forty eight nationalities, each possessing their own native language. Therefore in order for these students (Arabs and Non-Arabs) to be able to communicate together at school and outside school, they need to have one language which is common to all - this of course being English as it is the most widely used language amongst them. The same applies to contact outside the school setting. Most of the foreign students (non-Libyans) live in compounds surrounded by people from different multi-ethnic backgrounds including some Arabs. However, in so far as Arabic as first language group are concerned, one would certainly expect them to have more personal contact outside the school setting.

The 'Quality of contact with native-speaking people' scale is present as a significant (positive) correlation with 'Effort' $(P<0.01)$ even though, as was mentioned above, there was no significant correlation between the frequency of direct contact scale and the criterion measures. This could be related once again to the fact that students do enjoy meeting and conversing at school with friends who are Arabic speakers and outside the school environment with neighbours or when they go shopping but just as long as they can speak in English. Moreover, this analysis shows that students have integrative goals for learning Arabic. They obviously realise the benefits of learning the language even though they lack the contact with the people. In regards to the Arabic speakers one would expect that they do enjoy communicating with their families, friends and neighbours outside the school context in their native-language

As can be seen the high negative correlation between 'Anxiety' and 'Effort' clearly shows that anxiety affects effort which means that those students who are more anxious are not willing to exert as much effort as their less anxious counterparts. One hypothesis for this anxiety is that teachers' tend to be very strict with the students and also they have insufficient personal contact with the language. As can be seen 'Attitudes towards learning Arabic', 'Attitudes towards the lessons' and 'Attitudes towards the textbook' correlate positively with 'Effort' which undoubtedly will influence their motivation and in turn will generate effort towards learning this second language.

Thus, the above findings emphasise the importance of the learning situation level of student motivation, particularly the course-specific motivational components comprising the syllabus, materials, teaching method and tasks as outlined in Dörnyei's (1994) framework of L2 motivation. The results therefore give empirical support to Dörnyei's hypothetical construct. Further evidence to support this important finding can be found in eight studies conducted in different parts 
of the world. (Chambers, 1998, 1999; Clément et al 1994; Donitsa-Schmidt et al 2004; Inbar et al 1999, 2001; Mihaljević, 1996; Nikolov, 1999, Ozek \& Williams 1999). These scholars have been cited in the introduction. Parents are also influential figures in helping their children acquire an L2, as indicated by the significant positive correlation between 'External influences of parents' and 'Effort'. This is in agreement with a study carried out by MacIntyre, Baker, Clément \& Conrod (2001), where results indicated a particularly salient parental influence.

TABLE 4.

PEARSON PRODUCT-MOMENT CORRELATIONS BETWEEN MEASURES OF MOTIVATIONAL VARIABLES, EFFORT, MOTIVATED

\begin{tabular}{|c|c|c|c|}
\hline & EFFORT & $\begin{array}{l}\text { MOTIVATED } \\
\text { BEHAVIOUR }\end{array}$ & $\begin{array}{c}\text { EXAM } \\
\text { RESULTS }\end{array}$ \\
\hline Instrumental Orientation & $.38 * *$ & $.26^{* *}$ & .14 \\
\hline Integrative Orientation & $.45^{* *}$ & $.24 * *$ & .15 \\
\hline Attitudes Towards Studying Arabic & $.41 * *$ & $.23 * *$ & .09 \\
\hline Frequency of Direct Contact with Native People & $.14-$ & .10 & -.02 \\
\hline Frequency of Indirect Contact with Arabic & $.33 * *$ & $.23 * *$ & .04 \\
\hline Quality of Contact with Arabic & $.35^{* *}$ & $.20 *$ & -.02 \\
\hline Quality of Contact with Native-People of Arabic & $.29 * *$ & .00 & -.05 \\
\hline External Influences of Parents & $.36^{* *}$ & .06 & .07 \\
\hline Anxiety of Arabic & $-.31 * *$ & -.15 & $-.28 * *$ \\
\hline Expectations of Arabic & $.41 * *$ & $.28 * *$ & .09 \\
\hline Self-Evaluation of Arabic & $.41 * *$ & $.22 * *$ & .13 \\
\hline Desired Arabic Proficiency & $.40 * *$ & $.22 * *$ & $.26 * *$ \\
\hline Satisfaction with Arabic & $.45^{* *}$ & $.17^{*}$ & $.17^{*}$ \\
\hline Attitudes Towards Arabic Lessons & $.49 * *$ & $.29 * *$ & $.28 * *$ \\
\hline Attitudes Towards Arabic Textbook & $.47 * *$ & $.29 * *$ & $.25 * *$ \\
\hline Multiple correlation & $.67 * * *$ & $.49^{*}$ & $.47 *$ \\
\hline
\end{tabular}

$* P<0.05, * * P<0.01, * * * P<0.001$

\section{Grades 7, 8 and 9, 10 combined}

The results of the correlational analysis for Grades 7, 8 and 9, 10 are shown in Table 5. By splitting the sample into two sub-groups there are fewer significant correlations which are partly due to the reduced sample sizes. However, as can be seen in the table, another reason for the less clear cut picture is the difference between the two age groups. Motivation does not seem to play a very salient role in junior high school in determining outcomes whereas it does in senior high school, and the changes are the combined function of two reasons: 1) As we will see later, motivation has been found to decrease significantly in the higher years. This means that in junior high school there is an overall level of motivation with far less variance than in senior high school, which depresses correlation coefficients in general. 2) A second, more speculative, explanation is that as students mature their motivational perspectives become clearer: those who feel motivated and responded accordingly in the questionnaire really mean it, whereas in others demotivation has also been established by that stage.

As Table 5 shows, three motivational variables: 'Desired Arabic proficiency', 'Attitudes towards the lessons' and 'Attitudes towards the textbook' correlate positively with the three criterion measures for the lower grades. This shows that these components have a positive influence on the effort students' are willing to expend to learn this language as well as their motivation and L2 achievement.

TABLE 5.

PEARSON PRODUCT-MOMENT CORRELATIONS BETWEEN MEASURES OF MOTIVATIONAL VARIABLES, EFFORT, MOTIVATED BEHAVIOUR AND EXAMINATIONS RESULTS FOR GRADES 7, 8 AND 9, 10

\begin{tabular}{|c|c|c|c|c|c|c|}
\hline & \multicolumn{3}{|c|}{ GRADES $7 \& 8$} & \multicolumn{3}{|c|}{ GRADES $9 \& 10$} \\
\hline & EFFORT & $\begin{array}{l}\text { MOTIVATED } \\
\text { BEHAVIOUR }\end{array}$ & $\begin{array}{l}\text { EXAM } \\
\text { RESULTS }\end{array}$ & EFFORT & $\begin{array}{l}\text { MOTIVATE } \\
\text { BEHAVIOUR }\end{array}$ & $\begin{array}{c}\text { EXAM } \\
\text { RESULTS }\end{array}$ \\
\hline Instrumental Orientation & $.46^{* *}$ & $.33 *$ & .17 & $.27 *$ & .05 & .05 \\
\hline Integrative Orientation & $.51 * *$ & $.32 *$ & .14 & $.31^{*}$ & .09 & .07 \\
\hline Attitudes Towards Studying Arabic & $.55^{* *}$ & $.31 *$ & .12 & .17 & .08 & -.01 \\
\hline Frequency of Direct Contact & .20 & -.10 & .22 & .08 & -.18 & -.12 \\
\hline Frequency of Indirect Contact & $.36 * *$ & .19 & .13 & .21 & .19 & -.21 \\
\hline Quality of Contact with Arabic & $.49 * *$ & $.30^{*}$ & .21 & $.30^{*}$ & .17 & $-.31 *$ \\
\hline Quality of Contact with Native-People & $.31 *$ & .08 & .15 & .22 & -.07 & $-.27 *$ \\
\hline External Influences of Parents & $.44 * *$ & .01 & .01 & .13 & -.08 & -.02 \\
\hline Anxiety of Arabic & $-.37 * *$ & -.20 & $-.30 *$ & -.20 & -.02 & $-.27 *$ \\
\hline Expectations of Arabic & $.52 * *$ & $.35^{* *}$ & .20 & .10 & .15 & -.21 \\
\hline Self-Evaluation of Arabic & $.47 * *$ & .22 & .21 & .20 & .15 & -.06 \\
\hline Desired Arabic Proficiency & $.55^{* *}$ & $.37 * *$ & $.29 *$ & .15 & -.12 & .13 \\
\hline Satisfaction with Arabic & $.29^{*}$ & .08 & .06 & $.46^{* *}$ & .20 & .16 \\
\hline Attitudes Towards Arabic Lessons & $.61 * *$ & $.40 * *$ & $.36 * *$ & $.29 *$ & .08 & .16 \\
\hline Attitudes Towards Arabic Textbook & $.57 * *$ & $.36^{* *}$ & $.34 * *$ & .23 & .18 & .11 \\
\hline Multiple correlation & $.81 * * *$ & $.76^{* *}$ & .60 & $.73 *$ & .49 & .56 \\
\hline
\end{tabular}

Multiple correlation

$* P<0.05, * * P<0.01$ 
Anxiety appears to be associated more with learning Arabic amongst the lower grades (7 and 8) as shown by the negative relationship between 'Anxiety', 'Effort' and 'Examination results'. This could be related to the difference in teaching methodologies amongst the teachers as the elementary teachers are Libyans while in the high school they are mostly Iraqis. Therefore as students enter the high school they need to adapt to their new teachers' style of teaching.

\section{Non-Arabic as a first language group}

Looking at the results of the correlations for all the non-Arabic speakers as a first language group (Table 6) similarities can be found to those in Table 4 for the whole sample, which provides evidence for the validity of the study. In addition, the fact that the 'Frequency of indirect contact scale' showed no significant correlation with the criterion measures, is more than likely related to the students lack of L2 proficiency which is inhibiting them from enjoying the cultural artifacts of the L2 community. Furthermore, the negative correlation between 'Anxiety' with the criterion measures 'Effort' and 'Examination results' also reflects the findings in Table 5 that learners do experience anxiety learning this language.

TABLE 6.

PEARSON PRODUCT-MOMENT CORRELATIONS BETWEEN MEASURES OF MOTIVATIONAL VARIABLES, EFFORT, MOTIVATED BEHAVIOUR AND EXAMINATIONS RESULTS FOR ALL NON-ARABIC AS FIRST LANGUAGE GROUP

\begin{tabular}{llll}
\hline & & MOTIVATED & EXAM \\
& EFFORT & BEHAVIOUR & RESULTS \\
\hline Instrumental Orientation & $.34^{* *}$ & $.29^{* *}$ & $.22^{*}$ \\
Integrative Orientation & $.41^{* *}$ & $.25^{*}$ & .19 \\
Attitudes Towards Studying Arabic & $.36^{* *}$ & $.22^{*}$ & .11 \\
Frequency of Direct Contact with Arabic & -.01 & $-.22^{*}$ & -.06 \\
Frequency of Indirect Contact with Arabic & .19 & .13 & .01 \\
Quality of Contact with Arabic & $.24^{*}$ & .15 & -.07 \\
Quality of Contact with Native-People & .14 & -.15 & -.07 \\
External Influences of Parents & $.30^{* *}$ & -.01 & .14 \\
Anxiety of Arabic & $-.29^{* *}$ & -.15 & $-.27^{*}$ \\
Expectations of Arabic & $.28^{* *}$ & .19 & .07 \\
Self-Evaluation of Arabic & $.33^{* *}$ & .14 & .19 \\
Desired Arabic Proficiency & $.36^{* *}$ & $.22^{*}$ & $.26^{*}$ \\
Satisfaction with Arabic & $.34^{* *}$ & .05 & .19 \\
Attitudes Towards Arabic Lessons & $.45^{* *}$ & $.28^{* *}$ & $.30^{* *}$ \\
Attitudes Towards Arabic Textbook & $.40^{* *}$ & $.26^{*}$ & $.29^{* *}$ \\
\hline Multiple correlations & $.71^{* *}$ & .59 & .55 \\
\hline$* P<0.05$ & & & \\
\hline
\end{tabular}

$* P<0.05$

$* * P<0.01$

\section{One-way Analysis of Variance}

\section{The whole sample}

The results of the correlation analyses indicate that there are differences between the motivational dispositions of various subgroups in the whole sample. This warranted performing a one-way between group analysis of variance (ANOVA) to compare the mean scores of the motivational variables and criterion measures (effort and motivated behaviour) across these sub-groups.

TABLE 7.

THE RESULTS OF THE ONE-WAY ANALYSIS OF VAIRAINCE OF THE MOTIVATIONAL VARIABLE AND THE CRITERION MEASURES (EFFORT AND MOTIVATED BEHAVIOUR) AMONG GRADES 6, 7, 8, 9 AND 10

\begin{tabular}{|c|c|c|c|c|c|}
\hline & Grade & $M$ & SD & $\mathrm{F}$ & Sig. \\
\hline \multirow[t]{5}{*}{ Effort } & 6 & 4.28 & 0.59 & 3.05 & $0.02 *$ \\
\hline & 7 & 3.94 & 0.89 & & \\
\hline & 8 & 4.05 & 0.73 & & \\
\hline & 9 & 3.82 & 0.84 & & \\
\hline & 10 & 3.51 & 1.04 & & \\
\hline \multirow[t]{5}{*}{ Motivated Behaviour } & 6 & 5.96 & 1.41 & 1.52 & 0.20 \\
\hline & 7 & 5.11 & 1.66 & & \\
\hline & 8 & 5.69 & 1.20 & & \\
\hline & 9 & 5.55 & 1.37 & & \\
\hline & 10 & 5.29 & 1.57 & & \\
\hline \multirow[t]{5}{*}{ Instrumental Orientation } & 6 & 3.78 & 0.78 & 0.91 & 0.46 \\
\hline & 7 & 3.52 & 1.01 & & \\
\hline & 8 & 3.79 & 0.67 & & \\
\hline & 9 & 3.49 & 0.80 & & \\
\hline & 10 & 3.62 & 0.63 & & \\
\hline \multirow[t]{5}{*}{ Integrative Orientation } & 6 & 3.89 & 0.70 & 3.30 & $0.01 * *$ \\
\hline & 7 & 3.67 & 0.95 & & \\
\hline & 8 & 3.98 & 0.56 & & \\
\hline & 9 & 3.34 & 0.81 & & \\
\hline & 10 & 3.55 & 0.72 & & \\
\hline
\end{tabular}


Attitudes Towards Studying Arabic

Frequency of Direct Contact with Arabic

Frequency of Indirect Contact with Arabic

Quality of Contact with Arabic

Quality of Contact with Native-People of Arabic

External Influences of Parents

Anxiety of Arabic

Expectations of Arabic

Self-Evaluation of Arabic

Desired Arabic Proficiency

Satisfaction with Arabic

Attitudes Towards Arabic Lessons

Attitudes Towards Arabic Textbook

\begin{tabular}{|c|c|c|}
\hline 0.98 & \multirow[t]{5}{*}{1.39} & \multirow[t]{5}{*}{0.24} \\
\hline 1.15 & & \\
\hline 0.99 & & \\
\hline 1.03 & & \\
\hline 0.85 & & \\
\hline 1.27 & \multirow[t]{5}{*}{0.99} & \multirow[t]{5}{*}{0.41} \\
\hline 1.16 & & \\
\hline 1.22 & & \\
\hline 1.44 & & \\
\hline 1.09 & & \\
\hline 1.12 & \multirow[t]{5}{*}{1.27} & \multirow[t]{5}{*}{0.29} \\
\hline 0.92 & & \\
\hline 1.11 & & \\
\hline 0.87 & & \\
\hline 1.13 & & \\
\hline 1.13 & \multirow[t]{5}{*}{0.32} & \multirow[t]{5}{*}{0.86} \\
\hline 1.00 & & \\
\hline 1.00 & & \\
\hline 0.84 & & \\
\hline 1.23 & & \\
\hline 1.13 & \multirow[t]{5}{*}{0.06} & \multirow[t]{5}{*}{0.99} \\
\hline 1.32 & & \\
\hline 1.19 & & \\
\hline 1.32 & & \\
\hline 1.20 & & \\
\hline 0.85 & \multirow[t]{5}{*}{1.32} & \multirow[t]{5}{*}{0.27} \\
\hline 1.01 & & \\
\hline 0.88 & & \\
\hline 0.85 & & \\
\hline 0.66 & & \\
\hline 1.13 & 2.23 & 0.07 \\
\hline
\end{tabular}

1.13

1.08

0.90

0.81

0.83

$1.29 \quad 3.17 \quad .02 *$

1.25

1.28

1.04

1.15

$\begin{array}{lll}1.30 & 1.66 & 0.16\end{array}$

1.21

1.15

1.11

1.01

$\begin{array}{lll}1.04 & 0.99 & 0.42\end{array}$

1.29

0.82

1.07

0.92

1.37

1.23

1.4

1.10

0.99

1.76

1.92

1.53

1.51

1.17

1.72

1.88

1.65

1.53

1.39

**p $<0.01$

The scores across each of the five class groups are shown in Table 7 and the ANOVA results reveal highly significant differences with regard to a number of key motivational variables. Following the analysis, a post-hoc comparison was performed to see which groups differed significantly from one another (Table 8). Looking at the results in Table 8 , a very consistent pattern emerges as the variables that show age difference are always characterised by a decline with age particularly amongst the older learners (Grades 9 and 10). This powerful and consistent trend, which has parallels in the literature (see the review in the first part of the paper), is one of the most important findings of this study, and it will be further examined in the following analyses. Also, the follow up interviews will look into the 
broader issue of motivational change. This important finding indicates that the decrease of L2 motivation found with Arabic is not necessarily specific to the actual target language but is more general.

TABLE 8

POST-HOC COMPARISON OF THE MOTIVATIONAL VARIABLES AND CRITERION MEASURES AMONG GRADES 6, 7, 8, 9 AND 10 THAT SHOWED A SIGNIFICANCE BETWEEN-GROUP DIFFERENCE IN THE ANOVA

\begin{tabular}{|c|c|c|c|c|c|c|}
\hline & $\begin{array}{l}\text { Integrative } \\
\text { Orientation }\end{array}$ & Expectations & Effort & $\begin{array}{l}\text { Satisfaction } \\
\text { with Arabic }\end{array}$ & $\begin{array}{r}\text { Attitudes Towards } \\
\text { Arabic Textbook }\end{array}$ & $\begin{array}{l}\text { Examination } \\
\text { Results }\end{array}$ \\
\hline Grade 6 & $\overline{3.89}$ & 3.51 & 4.28 & $\overline{3.68}$ & $\overline{5.46}$ & $\overline{82.11}$ \\
\hline Grade 7 & 3.67 & 2.86 & 3.94 & 3.33 & 4.64 & 63.75 \\
\hline Grade 8 & 3.98 & 3.11 & 4.05 & 3.17 & 5.27 & 49.40 \\
\hline Grade 9 & 3.34 & 2.58 & 3.82 & 2.51 & 4.36 & 51.76 \\
\hline Grade 10 & 3.55 & 2.53 & 3.51 & 3.10 & 4.24 & 76.54 \\
\hline $\mathrm{F}$ & 3.30 & 3.17 & 3.05 & 4.10 & 3.02 & 15.74 \\
\hline $\mathrm{P}$ & .01 & .02 & .02 & .004 & .02 & .000 \\
\hline $\begin{array}{l}\text { Post-hoc } \\
\text { comparison }\end{array}$ & $8,6,7,10$ & $6,8,7$ & $6,8,7,9$ & $6,7,8,10$ & $6,8,7,9$ & 6,10 \\
\hline $\begin{array}{l}\text { LSDa (Least } \\
\text { Significant } \\
\text { Difference) }\end{array}$ & $7,10,9$ & $8,7,9,10$ & $8,7,9,10$ & $8,10,9$ & $8,7,9,10$ & 9,7 \\
\hline
\end{tabular}

${ }^{a}$ Numbers refer to students grades; numbers in the same line indicate non-significant mean differences

Once again these findings further support other empirical studies that found that motivation does not remain constant throughout the many years it takes to acquire a language (e.g. Dörnyei, 2000 and Ushioda, 1996). Researchers have shown time and again that there is a decline in motivation as the student gets older and progresses to higher grades. I will come back to this question when discussing the interview data.

\section{Grades 6 and 7}

TABLE 9.

THE RESULTS OF THE ONE-WAY ANALYSIS OF VAIRAINCE OF THE MOTIVATIONAL VARIABLE AND THE CRITERION MEASURES (EFFORT AND MOTIVATED BEHAVIOUR) AMONG GRADES 6 AND 7

\begin{tabular}{|c|c|c|c|c|c|}
\hline & Grade & M & SD & $\mathrm{F}$ & Sig. \\
\hline \multirow[t]{2}{*}{ Effort } & 6 & 4.28 & 0.59 & 2.99 & 0.09 \\
\hline & 7 & 3.94 & 0.89 & & \\
\hline \multirow[t]{2}{*}{ Motivated Behaviour } & 6 & 5.96 & 1.41 & 4.49 & $0.04 *$ \\
\hline & 7 & 5.11 & 1.66 & & \\
\hline \multirow[t]{2}{*}{ Instrumental Orientation } & 6 & 3.78 & 0.79 & 1.16 & 0.29 \\
\hline & 7 & 3.52 & 1.01 & & \\
\hline \multirow[t]{2}{*}{ Integrative Orientation } & 6 & 3.89 & 0.70 & 1.0 & 0.32 \\
\hline & 7 & 3.67 & 0.95 & & \\
\hline \multirow[t]{2}{*}{ Attitudes Towards Studying Arabic } & 6 & 3.68 & 0.98 & 1.0 & 0.32 \\
\hline & 7 & 3.41 & 1.15 & & \\
\hline \multirow[t]{2}{*}{ Frequency of Direct Contact with Arabic } & 6 & 3.13 & 1.27 & 2.70 & 0.11 \\
\hline & 7 & 3.65 & 1.15 & & \\
\hline \multirow[t]{2}{*}{ Frequency of Indirect Contact with Arabic } & 6 & 2.50 & 1.12 & 2.08 & 0.16 \\
\hline & 7 & 2.12 & 0.92 & & \\
\hline \multirow[t]{2}{*}{ Quality of Contact with Arabic } & 6 & 2.90 & 1.13 & 0.22 & 0.65 \\
\hline & 7 & 2.76 & 1.00 & & \\
\hline \multirow[t]{2}{*}{ Quality of Contact with Native-People of Arabic } & 6 & 3.42 & 1.13 & 0.07 & 0.80 \\
\hline & 7 & 3.34 & 1.31 & & \\
\hline \multirow[t]{2}{*}{ External Influences of Parents } & 6 & 4.03 & 0.85 & 0.67 & 0.42 \\
\hline & 7 & 3.83 & 1.01 & & \\
\hline \multirow[t]{2}{*}{ Anxiety of Arabic } & 6 & 2.54 & 1.13 & 1.78 & 0.19 \\
\hline & 7 & 2.92 & 1.08 & & \\
\hline \multirow[t]{2}{*}{ Expectations of Arabic } & 6 & 3.51 & 1.29 & 3.91 & $0.05 *$ \\
\hline & 7 & 2.86 & 1.25 & & \\
\hline \multirow[t]{2}{*}{ Self-Evaluation of Arabic } & 6 & 3.36 & 1.30 & 0.93 & 0.34 \\
\hline & 7 & 3.05 & 1.21 & & \\
\hline \multirow[t]{2}{*}{ Desired Arabic Proficiency } & 6 & 4.26 & 1.04 & 2.56 & 0.12 \\
\hline & 7 & 3.78 & 1.29 & & \\
\hline \multirow[t]{2}{*}{ Satisfaction with Arabic } & 6 & 3.68 & 1.37 & 1.09 & 0.30 \\
\hline & 7 & 3.33 & 1.23 & & \\
\hline \multirow[t]{2}{*}{ Attitudes Towards Arabic Lessons } & 6 & 5.72 & 1.76 & 1.18 & 0.28 \\
\hline & 7 & 5.20 & 1.92 & & \\
\hline \multirow[t]{2}{*}{ Attitudes Towards Arabic Textbook } & 6 & 5.46 & 1.72 & 3.10 & 0.83 \\
\hline & 7 & 4.60 & 1.88 & & \\
\hline
\end{tabular}

$* p<0.05, * * p<0.01$ 
Since a decline in attitudes and motivation is said to occur during the transition from elementary to middle school (Eccles \& Midgley, 1989), a comparison of the mean scores between Grades 6 and 7 was considered to be of importance in order to obtain a better understanding of what motivational factors influence motivation and L2 achievement. The results are presented in Table 9.

Comparing the mean scores of Grades 6 and 7 reveal a lack of significant results especially for Grade 7 students entering the high school, which shows that there does not seem to be a transitional break when it comes to Arabic. As a result of this, the students' motivational disposition towards Arabic does not change upon entering high school.

\section{Grades 7, 8 and 9, 10 combined}

The results of the mean scores for the one-way analysis of variance between the motivational variables and the criterion measures (effort and motivated behaviour) for Grades 7, 8 and 9, 10 (Table 10) reveal that the lower grades have obtained the highest scores for the three motivational components in comparison to the higher grades.

On the one hand, two of the results parallel closely those obtained by the correlations (Table 5) for the lower grades. They are 'Integrative orientation' and 'Attitudes towards the textbook' scales.

The results also show that the 'Satisfaction' and 'Attitudes towards the textbook' scales are also important components that influence motivation amongst these groups of learners. Besides this, the older students are significantly less motivated integratively than their younger counterparts.

TABLE 10.

THE RESULTS OF THE ONE-WAY ANALYSIS OF VAIRAINCE OF THE MOTIVATIONAL VARIABLE AND THE CRITERION MEASURES (EFFORT AND MOTIVATED BEHAVIOUR) AMONG GRADES 7, 8 AND 9, 10

\begin{tabular}{|c|c|c|c|c|c|}
\hline & Grade & M & SD & $\mathrm{F}$ & Sig. \\
\hline Effort & $\begin{array}{l}7+8 \\
9+10\end{array}$ & $\begin{array}{l}3.99 \\
3.69\end{array}$ & $\begin{array}{l}0.82 \\
0.93\end{array}$ & 3.31 & 0.07 \\
\hline Motivated Behaviour & $\begin{array}{l}7+8 \\
9+10\end{array}$ & $\begin{array}{l}5.37 \\
5.44\end{array}$ & $\begin{array}{l}1.49 \\
1.45\end{array}$ & 0.06 & 0.80 \\
\hline Instrumental Orientation & $\begin{array}{l}7+8 \\
9+10\end{array}$ & $\begin{array}{c}3.64 \\
3.54\end{array}$ & $\begin{array}{l}0.88 \\
0.73\end{array}$ & 0.46 & 0.50 \\
\hline Integrative Orientation & $\begin{array}{l}7+8 \\
9+10\end{array}$ & $\begin{array}{l}3.81 \\
3.43\end{array}$ & $\begin{array}{l}0.81 \\
0.77\end{array}$ & 6.73 & $0.01 * *$ \\
\hline Attitudes Towards Studying Arabic & $\begin{array}{l}7+8 \\
9+10\end{array}$ & $\begin{array}{l}3.55 \\
3.27\end{array}$ & $\begin{array}{l}1.08 \\
0.95\end{array}$ & 2.21 & 0.14 \\
\hline Frequency of Direct Contact with Arabic & $\begin{array}{l}7+8 \\
9+10\end{array}$ & $\begin{array}{l}3.47 \\
3.59\end{array}$ & $\begin{array}{l}1.19 \\
1.30\end{array}$ & 0.25 & 0.62 \\
\hline Frequency of Indirect Contact with Arabic & $\begin{array}{l}7+8 \\
9+10\end{array}$ & $\begin{array}{l}2.22 \\
2.03\end{array}$ & $\begin{array}{l}1.01 \\
0.98\end{array}$ & 1.06 & 0.31 \\
\hline Quality of Contact with Arabic & $\begin{array}{l}7+8 \\
9+10\end{array}$ & $\begin{array}{l}2.78 \\
2.89\end{array}$ & $\begin{array}{l}0.99 \\
1.03\end{array}$ & 0.31 & 0.58 \\
\hline Quality of Contact with Native-People of English & $\begin{array}{c}7+8 \\
9+10\end{array}$ & $\begin{array}{l}3.35 \\
3.46\end{array}$ & $\begin{array}{l}1.25 \\
1.26\end{array}$ & 0.19 & 0.66 \\
\hline External Influences of Parents & $\begin{array}{l}7+8 \\
9+10\end{array}$ & $\begin{array}{l}3.88 \\
3.63\end{array}$ & $\begin{array}{l}0.94 \\
0.78\end{array}$ & 2.34 & 0.13 \\
\hline Anxiety of Arabic & $\begin{array}{l}7+8 \\
9+10\end{array}$ & $\begin{array}{l}2.85 \\
2.59\end{array}$ & $\begin{array}{l}0.99 \\
0.87\end{array}$ & 2.29 & 0.13 \\
\hline Expectations of Arabic & $\begin{array}{l}7+8 \\
9+10\end{array}$ & $\begin{array}{l}2.97 \\
2.56\end{array}$ & $\begin{array}{l}1.26 \\
1.07\end{array}$ & 3.55 & 0.06 \\
\hline Self-Evaluation of Arabic & $\begin{array}{l}7+8 \\
9+10\end{array}$ & $\begin{array}{l}3.06 \\
2.75\end{array}$ & $\begin{array}{l}1.17 \\
1.07\end{array}$ & 2.21 & 0.14 \\
\hline Desired Arabic Proficiency & $\begin{array}{l}7+8 \\
9+10\end{array}$ & $\begin{array}{l}3.96 \\
3.99\end{array}$ & $\begin{array}{l}1.11 \\
1.00\end{array}$ & 0.04 & 0.85 \\
\hline Satisfaction with Arabic & $\begin{array}{l}7+8 \\
9+10\end{array}$ & $\begin{array}{l}3.26 \\
2.76\end{array}$ & $\begin{array}{l}1.18 \\
1.08\end{array}$ & 5.65 & $0.02 *$ \\
\hline Attitudes Towards Arabic Lessons & $\begin{array}{l}7+8 \\
9+10\end{array}$ & $\begin{array}{l}5.27 \\
5.08\end{array}$ & $\begin{array}{l}1.74 \\
1.38\end{array}$ & 0.43 & 0.51 \\
\hline Attitudes Towards Arabic Textbook & $\begin{array}{l}7+8 \\
9+10\end{array}$ & $\begin{array}{c}4.92 \\
4.31\end{array}$ & $\begin{array}{l}1.79 \\
1.46\end{array}$ & 4.06 & $0.05^{*}$ \\
\hline
\end{tabular}

$* p<0.05, * * p<0.01$

\section{English as a first language group, Arabic as a first language group and other nationalities learning Arabic}

As shown in this analysis, when it comes to Arabic there is no homogeneity in the school (see Table 11). This in fact is not surprising because the school was set up to represent a small microcosm of English within an Arabic country and therefore the main thrust is to develop a consistent positive disposition towards English amongst multicultural students. This binding force compensates for the mixed relations towards the host environment.

As can be seen in Table 11, there is a huge difference in regards to the mean scores and groups as the Arabic as a first language group has received the highest scores for fourteen motivational variables followed by the English as a first language group. Furthermore, low scores on the anxiety scale mean low anxiety level and as the results show the Arabic as a first language group are the least anxious towards learning this language in comparison to the other two groups. 
TABLE 11

ANALYSIS OF VARIABLE OF MOTIVATIONALE SCALES ACROSS THE THREE L1 GROUPS

\begin{tabular}{|c|c|c|c|c|c|}
\hline & Language & M & SD & $\mathrm{F}$ & Sig. \\
\hline \multirow[t]{3}{*}{ Effort } & English & 3.60 & 0.99 & 5.07 & $.007 * *$ \\
\hline & Arabic & 4.16 & 0.64 & & \\
\hline & Other & 3.94 & 0.86 & & \\
\hline \multirow[t]{3}{*}{ Motivated Behaviour } & English & 4.78 & 1.67 & 6.72 & $.002 * *$ \\
\hline & Arabic & 5.74 & 1.31 & & \\
\hline & Other & 5.81 & 1.34 & & \\
\hline \multirow[t]{3}{*}{ Instrumental Orientation } & English & 3.52 & 0.86 & 11.66 & $.000 * *$ \\
\hline & Arabic & 4.01 & 0.63 & & \\
\hline & Other & 3.32 & 0.77 & & \\
\hline \multirow[t]{3}{*}{ Integrative Orientation } & English & 3.59 & 0.87 & 12.41 & $.000 * *$ \\
\hline & Arabic & 4.05 & 0.62 & & \\
\hline & Other & 3.34 & 0.77 & & \\
\hline \multirow[t]{3}{*}{ Attitudes Towards Studying Arabic } & English & 3.49 & 1.03 & 15.32 & $.000 * *$ \\
\hline & Arabic & 3.96 & 0.78 & & \\
\hline & Other & 2.96 & 1.01 & & \\
\hline \multirow[t]{3}{*}{ Frequency of Direct Contact with Arabic } & English & 3.73 & 1.04 & 52.77 & $.000 * *$ \\
\hline & Arabic & 4.27 & 0.69 & & \\
\hline & Other & 2.40 & 1.12 & & \\
\hline \multirow[t]{3}{*}{ Frequency of Indirect Contact with Arabic } & English & 2.10 & 0.84 & 45.26 & $.000 * *$ \\
\hline & Arabic & 2.98 & 0.98 & & \\
\hline & Other & 1.50 & 0.54 & & \\
\hline \multirow[t]{3}{*}{ Quality of Contact with Arabic } & English & 2.57 & 0.93 & 14.78 & $.000 * *$ \\
\hline & Arabic & 3.37 & 0.96 & & \\
\hline & Other & 2.38 & 0.85 & & \\
\hline \multirow[t]{3}{*}{ Quality of Contact with Native-People of Arabic } & English & 3.36 & 1.10 & 19.31 & $.000 * *$ \\
\hline & Arabic & 4.06 & 0.92 & & \\
\hline & Other & 2.70 & 1.24 & & \\
\hline \multirow[t]{3}{*}{ External Influences of Parents } & English & 3.97 & 0.87 & 14.40 & $.000 * *$ \\
\hline & Arabic & 4.14 & 0.70 & & \\
\hline & Other & 3.34 & 0.84 & & \\
\hline \multirow[t]{3}{*}{ Anxiety of Arabic } & English & 3.08 & 0.92 & 24.71 & $.000 * *$ \\
\hline & Arabic & 2.05 & 0.84 & & \\
\hline & Other & 3.08 & 0.82 & & \\
\hline \multirow[t]{3}{*}{ Expectations of Arabic } & English & 2.68 & 1.12 & 29.36 & $.000 * *$ \\
\hline & Arabic & 3.75 & 1.02 & & \\
\hline & Other & 2.23 & 1.02 & & \\
\hline \multirow[t]{3}{*}{ Self-Evaluation of Arabic } & English & 2.65 & 0.97 & 73.12 & $.000 * *$ \\
\hline & Arabic & 4.04 & 0.79 & & \\
\hline & Other & 2.14 & 0.77 & & \\
\hline \multirow[t]{3}{*}{ Desired Arabic Proficiency } & English & 3.86 & 1.07 & 17.22 & $.000 * *$ \\
\hline & Arabic & 4.60 & 0.66 & & \\
\hline & Other & 3.54 & 1.12 & & \\
\hline \multirow[t]{3}{*}{ Satisfaction with Arabic } & English & 2.82 & 1.20 & 31.78 & $.000 * *$ \\
\hline & Arabic & 4.01 & 0.91 & & \\
\hline & Other & 2.50 & 0.99 & & \\
\hline \multirow[t]{3}{*}{ Attitudes Towards Arabic Lessons } & English & 5.16 & 1.63 & 24.52 & $.000 * *$ \\
\hline & Arabic & 6.26 & 0.95 & & \\
\hline & Other & 4.36 & 1.61 & & \\
\hline \multirow[t]{3}{*}{ Attitudes Towards Arabic Textbook } & English & 4.49 & 1.63 & 9.88 & $.000 * *$ \\
\hline & Arabic & 5.53 & 1.48 & & \\
\hline & Other & 4.20 & 1.71 & & \\
\hline
\end{tabular}

$* * p<0.01$

Arabs obviously have the most positive attitudes since we are talking here about their heritage language/culture, but the most negative ones are not the English speakers, but speakers of other languages for whom English is also a L2. For learners who are faced with two foreign languages English and Arabic, the choice is obvious - English - and Arabic is seen basically as a hindrance.

Interestingly, the 'Motivated behaviour' scale reveals some interesting findings as the other nationalities have received the highest score followed by the Arabic as a first language group. The results show that the Arabic teachers have evaluated the former group as being more motivated to learn this language. The reason for this could lie in the area of perceived relevance as the other nationalities could associate the relevance of learning Arabic in a way that the English and Arabic speakers fail to see. Whereas a number of Arab students in this study may regard English as being more relevant and useful to them for their future studies abroad, the other nationalities have also realised the importance of learning Arabic as they are living in an Arabic speaking country. It is also quite possible that they will also one day follow in the same footsteps as their parents and live and work in an Arabic speaking country.

Following this analysis a post-hoc test was performed to see which groups differed significantly from one another, (Table 12). As can be seen, Arabic as a first language group have obtained the most statistically significant scores at the $p<.01$ level for all the motivational variables except anxiety and the criterion measure motivated behaviour. There is 
also a great deal of variance between the scores. In regards to 'Anxiety' this grade obtained the lowest mean score of 2.05 which actually indicates that they have the lowest anxiety level towards learning this language.

Once again the English as a first language group and Arabic as a first language group have the least significant scores for the 'Motivated behaviour' scale, indicating that the other nationalities are more motivated to learn this language.

TABLE 12 .

POST-HOC COMPARISION OF MOTIVATIONAL VARIABLES AND CRITERION MEASURES AMONG ENGLISH AS A FIRST LANGUAGE GROUP, ARABIC AS A FIRST LANGUAGE GROUP AND OTHER NATIONALITIES THAT SHOWED A SIGNIFICANCE BETWEEN GROUP

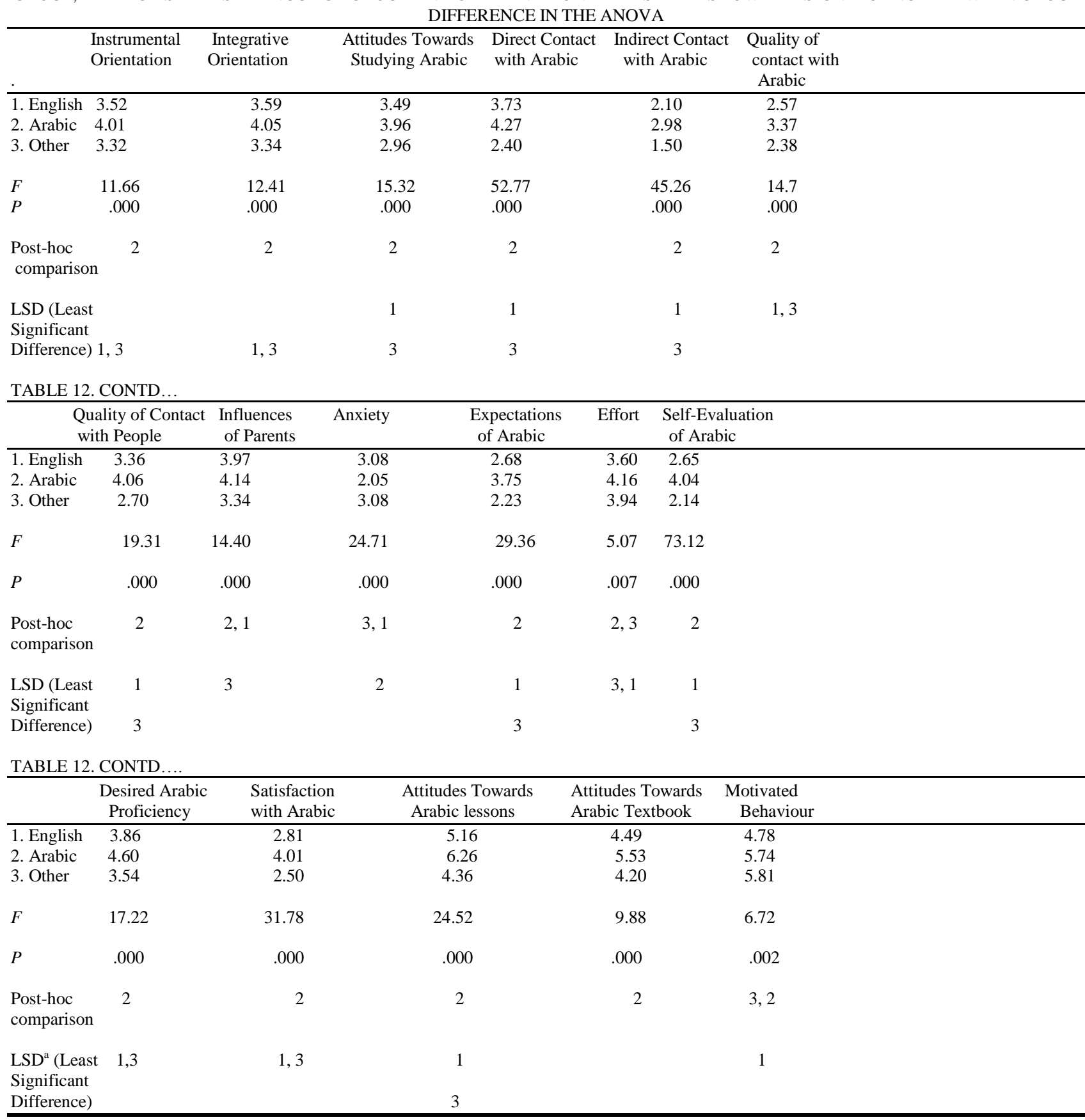

${ }^{a}$ Numbers refer to students grades; numbers in the same line indicate non-significant mean differences

\section{Interviews}

\section{How important is it for you to study Arabic?}

From the analysis of the interviews, it is evident that the majority of learners regard Arabic as being important to some degree. This is clear in their responses to Question 1. Some positive reasons for studying Arabic are: 'Arabic is my language.' Interestingly, this is how one student whose first language is English expressed her view about learning Arabic: "I'm in an Arab country and I'd like to know how to speak Arabic because people are Arabic".

\section{Changes in motivation}


As was mentioned earlier, the main objective of the semi-structured interviews was to try to obtain a more in depth explanation as to why the motivation of the older learners' in particular towards learning a second language decreases with age as they enter the senior high school.

The results of the interviews show some similarities and differences with those of the quantitative comparisons based on the questionnaire data as all the younger learners claim to have been motivated in Grade 6 and attributed this to their teacher. In contrast, however, all the younger learners said that their motivation decreased in Grades 7 and 8 . Once again the teacher was the most significant reason cited by the majority of students. It needs to be stressed that all but one of the younger learners who attributed their decrease in motivation to the teacher had actually been taught by the same teacher in both grades. A number of negative factors related to the teacher were mentioned, amongst them were: "he's strict and doesn't treat us nice"; "he's always shouting”; "he doesn't explain well; and "didn't teach me anything". In fact, one student stated that after he moved to another teacher's class during the middle of the first term his motivation actually increased again. This is what the student had to say: "Yes, it has increased because he's a good teacher. He doesn't shout at people and if you make a mistake he's like tells you that it's wrong and he helps you”.

The emerging patterns for Question 2 of the semi-structured interview also indicate that although the majority of older learners claim to have been motivated in Grades 7 and 8, their motivation decreased in the higher grades (Grades 9 and 10). Interestingly, the majority of older learners also attributed their decrease in motivation to the teacher. This is how some students described their feelings towards the language after being taught by their teacher: "I don't like Arabic anymore"; "I really hate Arabic"; "I don't like learning Arabic in class" and "in his class no one wants to learn Arabic".

The above finding casts more light on the temporal dimension of motivation and is in accordance with the findings of the post-hoc comparisons which revealed that age difference was characterised by a decline with age, particularly amongst the older learners. Students attributed their decrease in motivation mostly to the teachers and aspects related to the lessons. The teachers' findings are in accordance with the students as they also mentioned factors related to the teachers, such as, making classes interesting and explaining lessons clearly. This finding emphasises the importance of external factors related to the teacher and course-specific motivational components outlined in Dörnyei's (1994) framework of L2 motivation.

\section{The school's motivational influence}

Since students' motivation can be strongly affected by external and uncontrollable factors such as the school and the teachers' influence, Questions 3 and 4 attempted to elicit what students think the school and teachers can do to enhance their motivation. There is a consensus between the responses of the Arabic teachers and the older learners to the former question as they have cited the books as factors that can influence motivation. This finding is also in accordance with that of Chambers (1999) study as the textbook assumed considerable importance being placed second (after that of the teacher) in determining student attitudes towards the language course.

\section{The teacher's motivational influence}

To shed more light on the teacher's motivational influence, the responses to Question 4 showed that the majority of the older learners (Grades 9 and 10) mentioned that teachers should possess certain qualities amongst them are: (a) to be friendly and kind; (b) understand the students problems and help them; (c) to explain well/more; (d) make the lessons fun/interesting and (e) the teacher should be more interesting. Interestingly, 'stop shouting' was clearly one of the most significant responses cited by the majority of older learners.

As the above results and comments show the role of the teacher is an extremely complex one. Amongst other things teachers need to possess certain qualities that will help in providing intrinsic motivation, which include making their class interesting. The teacher also needs to be adept at ways of getting the students to learn the language without shouting at them in front of their peers.

Although Chambers (1999) study examined a very different population - British secondary school learners of German, the results of these interviews highlight his findings and shed more light on the fact that the teacher has a strong motivational influence on students despite what language is being learned.

\section{Other influential factors}

The results of Question 5 show that negative comments from peers can also have a devastating affect on motivation. This older learner explains how his friends' negative comments about the teacher and lessons strongly affect him: "It kind of makes me feel that it's not important, it's boring or the teacher is boring and stuff, yes".

\section{CONCLUSION}

The current study was aimed at finding out the extent in which various factors affect students' motivation and achievement in second language learning particularly as they enter the senior high school and whether motivation decreases with age. The results of the quantitative data and qualitative interviews give further support to the findings of empirical research conducted in different parts of the world which found that motivation does decline with age. It was hypothesised at the outset that factors related to the learning context would have the greatest effect on the students' language learning due to the students' lack of exposure to native-speaking people. The findings confirm this hyposthesis as there are a number of different factors that can have a motivational influence on students' during the course of their studies. In the eyes of the learners, the teacher is seen to be the key figure in determining the attitude to the language and in shaping motivation. Therefore, the teacher has the complex task of generating initial student motivation and 
helping students maintain it. The teacher's support, enthusiasm, positive approach in providing a learning experience which is interesting is an important motivational component. The above findings provide further evidence of the importance of the Learning Situation Level including Teacher-Specific and Course-Specific Components outlined in Dörnyei's (1994) framework of L2 motivation.

\section{REFERENCES}

[1] Chambers, G. N. (1998). Pupils' Perceptions of the Foreign Language Learning Experience. Language Teaching Research, 2,3: 231-259.

[2] Chambers, G. (1999). Motivating Language Learners. Multilingual Matters, Clevedon.

[3] Clément, R., Dörnyei, Z., \& Noels, K. A. (1994). Motivation, Self-confidence and Group Cohesion in the Foreign Language Classroom. Language Learning, 44: 417-48.

[4] Crookes, G. \& Shmidt, R. W. (1991). Motivation: Reopening the Research Agenda. Language Learning, 41: 469-512.

[5] Donitsa-Schmidt, S., Inbar, O., and Shohamy, E. (2004). The Effects of Teaching Spoken Arabic on Student's Attitudes and Motivation in Israel. The Modern Language Journal, 88: 217-228.

[6] Dörnyei, Z. (1994). Motivation and Motivating in the Foreign Language Classroom. The Modern Language Journal, 78: $273-$ 84.

[7] Dörnyei, Z. (1998). Motivation in Second Language and Foreign Language Learning. Language Teaching, 31: 117-35.

[8] Dörnyei, Z. (2000). Motivation in Action: Towards a Process-Oriented Conceptualisation of Student Motivation. British Journal of Educational Psychology, 70: 519-38.

[9] Dörnyei, Z. (2001). Teaching and Researching Motivation. Harlow: Longman.

[10] Dörnyei, Z. (2002). The Motivational Basis of Language Learning Tasks. In Individual Differences and Instructed Language Learning. John Benjamins Publishing Company. 137-58

[11] Dörnyei, Z. (2008). New ways of motivating foreign language learners: Generating vision. Links, 38 (Winter), 3-4.

[12] Eccles, J. S. \& Midgley, C. (1989). Stage/Environment Fit: Developmentally Appropriate Classrooms for Early Adolescents. In: R. Ames \& C. Ames (Eds.), Research on Motivation in Education: 3: 139-181. New York: Academic Press.

[13] Egbert, J. (2003). A Study of flow theory in the Foreign language Classroom. The Modern Language Journal, 87: $499-518$.

[14] Ellis, R. (1985). Understanding Second Language Acquisition. Oxford University Press.

[15] Gardner, R.C. (1985). Social Psychology and Second Language Learning. The Role of Attitudes and Motivation. Edward Arnold, London.

[16] Gardner, R. C. (1996). Motivation and Second Language Acquisition: Perspectives. Journal of the CAAL, 18: 19-42.

[17] Gardner, R.C., Masgoret, A-M., Tennant, J., Mihic, L. (2004). Integrative Motivation: Changes During a Year-Long Intermediate-Level. Language Learning, 54: 1-34.

[18] Guilloteaux, M. J. \& Dörnyei, Z. (2009). Reply to Rod Ellis's comment on "Motivating language learners: A classroomoriented investigation of the effects of motivational strategies on student motivation". TESOL Quarterly, 43(1), 109-111.

[19] Hardré, P. L. \& Sullivan, D. W. (2008). Student differences and environment perceptions: How they contribute to student motivation in rural high schools. Learning and Individual Differences, 18(4), 471-485.

[20] Inbar, O., Donitsa-Schmidt, S., \& Shohamy, E. (2001). Students' Motivation as a Function of Language Learning: The Teaching of Arabic in Israel. In: Z. Dörnyei \& R. Schmidt (Eds.), Motivation and Second Language Acquisition (Technical Report No. 23: 297-311. Honolulu: University of Hawai'i, Second Language Teaching and Curriculum Centre.

[21] Inbar, O., Shohamy, E., and Donitsa-Schmidt, S. (1999, March) The Effect of Teaching Spoken Arabic Dialect on Student's Attitudes, Motivation and Communicative Competence in Israel. Paper presented at the meeting of the American Association for Applied linguistics (AAAL). Stamford, CT.

[22] Julkunen, K. (1990). Open and Closed Vocabulary Tasks in Foreign Language Learning. In: J. Tommola (Ed.), Foreign Language Comprehension and Production. Publications of AfinLA 48: 7-25. Turku, Finland: AfinLA.

[23] Julkunen, K. (1994). Gender Differences in Students' Situation- and Task-Specific Foreign Language Learning Motivation. In: Tella, S. (Ed.) 1994. Nayton Paikka. Opetuksen Kuulttuurin Arviointi. Osa I. Helsingin Yliopiston Opettajankoulutuslaitos. Tutkimuksia, 129: 171-80.

[24] Julkunen, K. (2001). Situation- and Task-Specific Motivation in Foreign Language Learning. In: Z. Dörnyei \& R. Schmidt (Eds.), Motivation and Second Language Acquisition (Technical Report No. 23: 29-41. Honolulu: University of Hawai'i, Second Language Teaching and Curriculum Centre.

[25] MacIntyre, P. D., Baker, S. C., Clément, R., \& Conrod, S. (2001). Willingness to Communicate, Social Support, and Language - Learning Orientations of Immersion Students. Studies in Second language Acquisition, 23: 369-88.

[26] Mihaljević, J. (1990). Research on Motivation for Learning English as a Foreign Language. Studia Romanica Et Anglica Zagrabiensia, 35: 151-60.

[27] Mihaljević, J. (1992). Attitudes Towards the Teacher as a Factor in Foreign Language Learning. Studia Romanica Et Anglica Zagrabiensia, 37: 143-52.

[28] Mihaljević, J. (1994). Variation in Learner Effort - Effects of the Teaching Setting. Studia Romanica Et Anglica Zagrabiensia, 39: $53-57$

[29] Mihaljević, J. (1996). EFL Learning: The Effect of Affect. Second and Foreign Language Acquisition. In: A., Nizegorodcew \& A. Kosiarz-Stolarska (Eds.), Towarzystwo-Autorow I Wydawcow Prac Naukowych: 69-74. UNIVERSITAS, Krakow.

[30] Nikolov, M. (1999). 'Why Do You Learn English?' 'Because the Teacher is Short.' A Study of Hungarian Children's Foreign Language Learning Motivation. Language Teaching Research, 3,1: 33-56.

[31] Ozek, T. \& Williams, M. (1999). The Influence of Various Motivational Factors on Foreign Language Learning. In Individual Differences in Foreign Language Learning: Effects of Aptitude, Intelligence and Motivation. Conference Proceedings March $26^{\mathrm{th}}$ and $27^{\mathrm{th}}: 69-82$. 
[32] Ryan, A. M. \& Patrick, H. (2001). The Classroom Social Environment and Changes in Adolescents Motivation and Engagement During Middle School. American Educational Research Journal, 38: 437-60.

[33] Tachibaba, Y., Matsukawa, R., Zhong, Q. X. (1996). Attitudes and Motivation for Learning English: A Cross-national Comparison of Japanese and Chinese High School Students. Psychological Reports, 79: 691-700.

[34] Ushioda, E. (1996). Learner Autonomy 5: The Role of Motivation. Authentik, Dublin.

[35] Williams, M. Burden, R., (1997). Psychology for Language Teachers. Cambridge University Press, Cambridge.

[36] Williams, M. \& Burden, R. L, (1999). Students' Developing Conceptions of Themselves as Language Learners. The Modern Language Journal, 83: 193-201.

[37] Williams, M., Burden, R. L., \& Al-Baharna, S. (2001). Making Sense of Success and Failure: The Role of the Individual in Motivation Theory. In: Z. Dörnyei \& R. Schmidt (Eds.), Motivation and Second Language Acquisition (Technical Report No. 23: 171-84. Honolulu: University of Hawai'i, Second Language Teaching and Curriculum Centre.

[38] Williams, M., Burden, R. L., \& Lanvers, V. (2002). 'French is the language of Love and Stuff': Student Perceptions of Issues related to Motivation in Learning a Foreign Language. British Educational Research Journal, 28: 503-28.

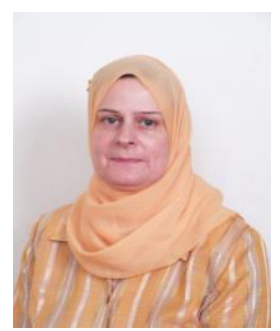

Pauline Ghenghesh was born in Liverpool, U.K. in 1959. She completed her PhD in 2005 in the area of motivation related to teaching and learning from the University of Nottingham in the U.K.

She has teaching experience at primary, secondary, high school, undergraduate and postgraduate levels in various parts of the world, including Brazil, Libya, the U.K., Egypt and Saudi Arabia. She currently holds the position of Lecturer at the British University in Egypt. She has published articles and books. Amongst them are three textbooks: English for Medical Students, ELGA Publications, 1996; Basic English for Children (1), General Company for Paper and Printing, Tripoli, 2001; Basic English for Children (2), Al An Printing and Publishing, Lebanon, 2004.

Dr. Ghenghesh's main research interests include student and teacher motivation, ESL writing, teacher development and materials development. 